University of Nebraska - Lincoln

DigitalCommons@University of Nebraska - Lincoln

West Central Research and Extension Center, North Platte

Agricultural Research Division of IANR

2011

\title{
Heifer development systems: Dry-lot feeding compared with grazing dormant winter forage
}

Richard N. Funston

University of Nebraska West Central Research and Extension Center, North Platte, rfunston2@unl.edu

D. M. Larson

University of Nebraska West Central Research and Extension Center, North Platte

Follow this and additional works at: https://digitalcommons.unl.edu/westcentresext

Part of the Agriculture Commons

Funston, Richard N. and Larson, D. M., "Heifer development systems: Dry-lot feeding compared with grazing dormant winter forage" (2011). West Central Research and Extension Center, North Platte. 18. https://digitalcommons.unl.edu/westcentresext/18

This Article is brought to you for free and open access by the Agricultural Research Division of IANR at DigitalCommons@University of Nebraska - Lincoln. It has been accepted for inclusion in West Central Research and Extension Center, North Platte by an authorized administrator of DigitalCommons@University of Nebraska - Lincoln. 


\section{JOURNAL OF ANIMAL SCIENCE}

The Premier Journal and Leading Source of New Knowledge and Perspective in Animal Science

Heifer development systems: Dry-lot feeding compared with grazing dormant winter forage

R. N. Funston and D. M. Larson

J Anim Sci 2011. 89:1595-1602.

doi: $10.2527 /$ jas.2010-3095

The online version of this article, along with updated information and services, is located on the World Wide Web at:

http://jas.fass.org/cgi/content/full/89/5/1595 


\title{
Heifer development systems: Dry-lot feeding compared with grazing dormant winter forage ${ }^{1}$
}

\author{
R. N. Funston ${ }^{2}$ and D. M. Larson \\ University of Nebraska West Central Research and Extension Center, North Platte 69101
}

\begin{abstract}
Two hundred ninety-nine Angusbased, nulliparous heifers (253 $\pm 2 \mathrm{~kg}$ initial BW) from 3 production years were utilized to compare traditional postweaning dry lot (DL) development with a more extensive winter grazing system utilizing a combination of corn residue and winter range (EXT). Heifers developed in the DL were offered a common diet after the weaning period for $208 \mathrm{~d}$ in yr 1, $194 \mathrm{~d}$ in yr 2, and $150 \mathrm{~d}$ in yr 3 until breeding. Heifers developed in EXT grazed corn residue for $135 \mathrm{~d}$ in yr 1, $106 \mathrm{~d}$ in yr 2, and $91 \mathrm{~d}$ in yr 3, and then fed in the DL until breeding (yr 1) or grazed dormant winter grass for approximately $60 \mathrm{~d}$ before being fed in the DL (yr 2 and 3). All 3 years, heifers were estrus synchronized, with timed AI performed in yr 1 . In yr 2 and 3, estrus was detected and those detected in estrus were artificially inseminated approximately 12 $\mathrm{h}$ later. Heifers were exposed to bulls $10 \mathrm{~d}$ after the last AI for $60 \mathrm{~d}$ while grazing summer pasture. During the winter grazing period, EXT heifers gained less
\end{abstract}

$(P=0.01)$ BW than DL heifers and EXT heifers had lighter $(P=0.02) \mathrm{BW}$ at breeding. Fewer $(P<0.01)$ EXT heifers reached puberty before breeding. Conception to AI was not different $(P=0.23)$; however, AI pregnancy rate tended $(P=0.08)$ to be less in EXT heifers. Final pregnancy rates were not different $(P=$ 0.38 ) between treatment groups. Although EXT heifers had lighter $(P=0.02)$ BW at pregnancy diagnosis; however, they did compensate with greater $(P=0.05)$ ADG after breeding, resulting in similar $(P=0.22)$ precalving BW. Winter development system did not influence $(P>0.10)$ percentage of calving in the first $21 \mathrm{~d}$, calf birth date, and calf birth BW, or dystocia score. Pregnancy rate after the second breeding season was not different $(P=0.56)$ between treatments. Heifer development using extended winter grazing reduced $(P$ $<0.01)$ the cost of producing a pregnant heifer by $\$ 45$ compared with DL.

Key words: calf production, corn residue, dry lot, heifer development, reproduction

(0)2011 American Society of Animal Science. All rights reserved.

J. Anim. Sci. 2011. 89:1595-1602 doi:10.2527/jas.2010-3095

\section{INTRODUCTION}

Current recommendations indicate a heifer should reach approximately $65 \%$ of mature BW by the first insemination for successful reproduction (Short and Bellows, 1971; Patterson et al., 1992). Rising input costs have increased interest in reduced-cost heifer development systems. Feeding replacement heifers to traditional target $\mathrm{BW}$ increased development costs relative to development systems where heifers were developed to lighter target BW ranging from 51 to $57 \%$ of mature BW (Funston and Deutscher, 2004; Roberts et al.,

\footnotetext{
${ }^{1}$ A contribution of the University of Nebraska Agricultural Research Division, supported in part by funds provided through the Hatch Act. Mention of a trade name, proprietary products, or company name is for presentation clarity and does not imply endorsement by the authors or the University of Nebraska.

${ }^{2}$ Corresponding author: rfunston2@unl.edu

Received April 19, 2010.

Accepted January 24, 2011.
}

2007, 2009; Martin et al., 2008; Larson et al., 2009). Feeding to prebreeding BW as light as $51 \%$ of mature BW was shown to be more cost effective than development to $57 \%$ of mature BW (Martin et al., 2008). Previous research on decreased ADG heifer development has been conducted completely in the dry lot (DL), under controlled conditions. Therefore, we hypothesized developing heifers in a more extensive, postweaning grazing system would not negatively affect reproductive performance. Specifically, our objectives were to evaluate postweaning replacement heifer development using a more extensive winter grazing system utilizing a combination of corn residue and winter range compared with traditional dry lot development to generate different target BW at breeding.

\section{MATERIALS AND METHODS}

The University of Nebraska-Lincoln Institutional Animal Care and Use Committee approved the procedures and facilities used in these experiments. 
Table 1. Nutrient analysis (DM basis) of corn residue, winter range, and supplement consumed by beef heifers during winter grazing

\begin{tabular}{lcccc}
\hline \hline Item & $\mathrm{CP}, \%$ & $\mathrm{RUP}, \% \mathrm{CP}$ & $\mathrm{NE}_{\mathrm{g}}$, Mcal $/ \mathrm{kg}$ & Intake, $\mathrm{kg} / \mathrm{d}$ \\
\hline Corn residue $^{1}$ & 6.5 & 31.0 & 0.91 & 6.43 \\
Upland winter range $^{1}$ & 4.7 & 37.0 & 0.44 & 6.43 \\
Supplement $^{2}$ & 31.4 & 47.6 & - & 0.45 \\
\hline
\end{tabular}

${ }^{1}$ National Research Council values (NRC, 2000).

${ }^{2}$ Supplement: $62 \%$ dried distillers grain plus solubles, $11 \%$ wheat middlings, $9 \%$ cottonseed meal, $5 \%$ dry corn gluten feed, $5 \%$ molasses, $2 \%$ urea, $6 \%$ vitamin and trace mineral premix, $80 \mathrm{mg} \cdot$ animal $^{-1} \cdot \mathrm{d}^{-1}$ of Rumensin (Elanco Animal Health, Indianapolis, IN).

Two hundred ninety-nine March-born, nulliparous heifers $(253 \pm 2 \mathrm{~kg}$ initial BW) from 3 production years were utilized to compare traditional postweaning DL development with a more extensive winter grazing system utilizing a combination of corn residue and winter range (EXT) during the same period. The heifers were predominately Angus-based and purchased from local producers.

Immediately after weaning, heifers were transported to the University of Nebraska West Central Research and Extension Center (WCREC), North Platte. Heifers arrived at the WCREC $7 \mathrm{~d}$ before the beginning of the study in yr 1 and 2 and consumed a receiving diet (DM basis) containing wet corn gluten feed (WCGF; $17 \%)$, corn silage $(23 \%)$, and hay $(60 \%)$. Heifers were received $26 \mathrm{~d}$ before the beginning of the study in $\mathrm{yr}$ 3 and consumed a receiving diet (DM basis) containing WCGF (41\%), hay (52\%), and a supplement (7\%). After the receiving period in each year, heifers were blocked by initial BW and source herd (if obtained from more than one location) and randomly assigned to either winter graze or to consume a common diet in a DL.

After the weaning period, heifers assigned to EXT were shipped to corn residue fields (CR) on approximately November 15 and returned to WCREC between February and April each year as dictated by weather conditions. The CR fields were approximately 40 ha, irrigated, planted in April, and harvested in October, with an average annual yield of 12,544 kg/ha. Stocking rate was approximately 2.5 heifers/ha for the grazing period each year. Heifers were offered the equivalent of $0.45 \mathrm{~kg} / \mathrm{d}$ of a $31 \% \mathrm{CP}$ (Table 1; DM basis) supplement delivered 3 times per week, which also supplied 80 $\mathrm{mg} \cdot$ animal $^{-1} \cdot \mathrm{d}^{-1}$ of monensin (Rumensin, Elanco Animal Health, Indianapolis, IN). Monensin allotment was based on previous research on grazing CR (Faulkner et al., 1985). Heifers grazed CR for $135 \mathrm{~d}$ in yr 1, 106 $\mathrm{d}$ in $\mathrm{yr} 2$, and $91 \mathrm{~d}$ in yr 3 . Variation in weather affected corn harvesting date, which affected how many days of CR grazing were available each year. A single morning BW was taken before and after winter grazing in each year because facilities did not permit monthly weighing. Subsequently, heifers were transported back to WCREC and group-fed in a DL for $79 \mathrm{~d}$ in yr 1 (Table 2), grazed dormant winter pasture for approximately $54 \mathrm{~d}$ and subsequently placed in the DL for 54 $\mathrm{d}$ in yr 2 (Table 3 ), and grazed dormant winter pasture for $63 \mathrm{~d}$ and subsequently placed in the DL for $47 \mathrm{~d}$ in yr 3 (Table 4), before breeding. Because of greater snow cover in yr 2 and 3 , heifers had to be removed from corn residue earlier and were placed on winter range to provide an alternative winter grazing source. Heifers grazing dormant winter pasture were supplemented similarly as on CR. Heifers were then placed in the DL at least 2 wk before the synchronization period for diet acclimation. Nutrient concentrations and intake estimates of winter forage were derived from NRC (2000) values (Table 1 ).

The winter pastures included a mixture of silty, silty overflow, and limy upland range sites with soils classified as Cozad, Coly, or Uly silt loam and slopes ranging from nearly level to 20 percent. Range condition was classified as good. A mixture of native, warm- and cool-season grass species were present. The primary warm-season species were little bluestem [Schizachyrium scoparium (Michx.) Nash], sideoats grama [Bouteloua cutipendula (Michx.) Torr.], blue grama [Bouteloua gracilis (Willd. ex Kunth) lag. ex Griffiths], big bluestem (Andropogon

Table 2. Composition and nutrient analysis of dry lot diets fed to heifers, yr 1

\begin{tabular}{|c|c|c|}
\hline Item (DM basis) & $\begin{array}{c}\mathrm{DL},{ }^{1} \\
208 \mathrm{~d}\end{array}$ & $\begin{array}{c}\mathrm{EXT}^{2} \\
79 \mathrm{~d}\end{array}$ \\
\hline DDGS, ${ }^{3} \%$ & 12 & 10 \\
\hline Corn silage, $\%$ & 23 & 16 \\
\hline Brome hay, \% & 60.5 & 69 \\
\hline Supplement ${ }^{4} \%$ & 4.5 & 5 \\
\hline Intake, $\mathrm{kg} / \mathrm{d}$ & 6.8 & 6.0 \\
\hline \multicolumn{3}{|c|}{ Diet nutrient analysis, ${ }^{5} \%$} \\
\hline $\mathrm{CP}, \%$ & 14.7 & 14.8 \\
\hline RUP, \% CP & 28.2 & 26.9 \\
\hline Crude fat, $\%$ & 3.6 & 3.3 \\
\hline $\mathrm{NE}_{\mathrm{g}}, \mathrm{Mcal} / \mathrm{kg}$ & 0.88 & 0.81 \\
\hline Dietary cost, $\$ / \mathrm{d}$ & 0.72 & 0.63 \\
\hline
\end{tabular}

${ }^{1} \mathrm{DL}=$ heifers developed in a dry lot from weaning through the end of AI breeding.

${ }^{2} \mathrm{EXT}=$ heifers that previously grazed corn residue offered a dry lot diet for $79 \mathrm{~d}$ through the end of AI breeding.

${ }^{3}$ Dried distillers grain plus solubles.

${ }^{4}$ Ground corn, calcium carbonate, salt, trace mineral mix, and vitamin mix, formulated to provide $200 \mathrm{mg}$ of Rumensin (Elanco Animal Health, Greenfield, IN).

${ }^{5}$ Wet chemistry, Ward Laboratories Inc., Kearney, NE; RUP based on NRC (2000). 
Table 3. Composition and nutrient analysis of dry lot diets fed to heifers, yr 2

\begin{tabular}{|c|c|c|}
\hline Item (DM basis) & $\begin{array}{c}\text { DL }{ }^{1} \\
194 \mathrm{~d}\end{array}$ & $\begin{array}{c}\mathrm{EXT}^{2} \\
54 \mathrm{~d}\end{array}$ \\
\hline WCGF ${ }^{3} \%$ & 20 & 15 \\
\hline Corn silage, $\%$ & 30 & 30 \\
\hline Brome hay, $\%$ & 45.5 & 50.5 \\
\hline Supplement, ${ }^{4} \%$ & 4.5 & 4.5 \\
\hline Intake, $\mathrm{kg} / \mathrm{d}$ & 6.9 & 6.8 \\
\hline \multicolumn{3}{|c|}{ Diet nutrient analysis, ${ }^{5} \%$} \\
\hline $\mathrm{CP}, \%$ & 14.3 & 13.8 \\
\hline RUP, \% CP & 23.0 & 23.1 \\
\hline Crude fat, \% & 2.8 & 2.7 \\
\hline $\mathrm{NE}_{\mathrm{g}}, \mathrm{Mcal} / \mathrm{kg}$ & 0.98 & 0.93 \\
\hline Dietary cost, $\$ / \mathrm{d}$ & 0.77 & 0.71 \\
\hline
\end{tabular}

${ }^{1} \mathrm{DL}=$ heifers developed in a dry lot from weaning through the end of AI breeding.

${ }^{2} \mathrm{EXT}=$ heifers that previously grazed corn residue and dormant winter range then offered a dry lot diet for $54 \mathrm{~d}$ through the end of AI breeding.

${ }^{3}$ Wet corn gluten feed.

${ }^{4}$ Ground corn, calcium carbonate, salt, trace mineral mix, and vitamin mix, formulated to provide $200 \mathrm{mg}$ of Rumensin (Elanco Animal Health, Greenfield, IN).

${ }^{5}$ Wet chemistry, Ward Laboratories Inc., Kearney, NE; RUP based on NRC (2000).

gerardii Vitman), and switchgrass (Panicum virgatum L.). Western wheatgrass (Agropyron smithii Rydb.), Scribner's panicum [Dicanthelium oligosanthes (Schult.) Gould var. scribnerianum (Nash) Gould], needle-andthread (Stipa comata Trin. \& Rupr.), and Kentucky bluegrass (Poa pratensis L.) were dominant cool-season species. Average annual herbage production is approximately $1,430 \mathrm{~kg} / \mathrm{ha}$.

Heifers assigned to the DL were group-fed after the weaning period for $208 \mathrm{~d}$ in yr 1 (Table 2), $194 \mathrm{~d}$ in yr 2 (Table 3), and $150 \mathrm{~d}$ in yr 3 (Table 4) until breeding. Diets were formulated to achieve an ADG allowing heifers to reach approximately $65 \%$ of mature BW $(360 \mathrm{~kg})$ immediately before AI. Diets were also formulated to meet or exceed NRC (2000) requirements for CP, trace minerals, and vitamins. Further, the diet supplied 200 $\mathrm{mg} \cdot$ animal $^{-1} \cdot \mathrm{d}^{-1}$ monensin (Rumensin, Elanco Animal Health). Diet ingredients and inclusion rate in DL was dependent upon ingredient availability and nutrient analysis (wet chemistry, Ward Laboratories Inc., Kearney, NE; RUP based on NRC, 2000) and designed to provide a similar ADG each year. Heifers were weighed monthly, and DMI was adjusted based on monthly BW measurements. Diets were provided once daily in the morning.

In yr 1 , estrus was synchronized by adding $0.5 \mathrm{mg} / \mathrm{d}$ of melengesterol acetate (MGA) to the diet for $14 \mathrm{~d}$, followed by a single 5-mL intramuscular (i.m.) injection of $\mathrm{PGF}_{2 \alpha}$ (PGF; Prostamate, Teva Animal Health Inc., St. Joseph, MO) $19 \mathrm{~d}$ after the end of MGA feeding. Approximately $66 \mathrm{~h}$ after the PGF injection, heifers received a single 2-mL i.m. injection of $\mathrm{GnRH}$ (Ova-Cyst, Teva Animal Health Inc.) and timed AI was performed. In yr 2 and 3, estrus was synchronized by adding MGA to the diet for $14 \mathrm{~d}$, followed by a single 5-mL i.m. injection of PGF (Prostamate, Teva Animal Health Inc.) $19 \mathrm{~d}$ after the end of MGA feeding. Heifers were combined into 1 breeding group, and estrus detection was performed for approximately $5 \mathrm{~d}$ after the PGF injection. Artificial insemination was performed $12 \mathrm{~h}$ after standing estrus detection. In all years, heifers were inseminated with semen from predominantly Simmental bulls. Approximately $10 \mathrm{~d}$ after AI, heifers were exposed to fertile bulls at a rate of at least 1 bull:50 heifers for $60 \mathrm{~d}$. Heifers not detected in estrus in yr 2 and 3 were placed with bulls immediately after heat detection ceased and given PGF 5 d later. Approximately $45 \mathrm{~d}$ after AI, first service conception was determined via transrectal ultrasonography. Final pregnancy rate was determined via transrectal ultrasonography $45 \mathrm{~d}$ after bulls were removed.

During the subsequent winter period, all pregnant heifers grazed $\mathrm{CR}$ and were offered the equivalent of $0.45 \mathrm{~kg} / \mathrm{d}$ of a $31 \%$ CP (DM basis; Table 1) supplement provided 3 times per week. Heifer BW was measured before calving. At parturition, calf BW, dystocia score, and calf sex were recorded.

In all years after calving, heifers consumed a DL diet through AI breeding. Approximately $60 \mathrm{~d}$ after calving in all years, estrus was synchronized using a controlled internal drug-releasing device (Eazi-Breed CIDR, Pfizer Animal Health, New York, NY), Co-Synch protocol with timed AI (TAI) in all heifers who calved. All cows were administered a single 2-mL i.m. injection of GnRH (Ova-Cyst, Teva Animal Health Inc.), and a CIDR was inserted. Seven days after CIDR insertion, the CIDR was removed and all cows received a single 5-mL i.m. injection of PGF (Prostamate, Teva Animal Health

Table 4. Composition and nutrient analysis of dry lot diets fed to heifers, yr 3

\begin{tabular}{|c|c|c|}
\hline Item (DM basis) & $\begin{array}{c}\mathrm{DL},{ }^{1} \\
150 \mathrm{~d}\end{array}$ & $\begin{array}{c}\mathrm{EXT}^{2}{ }^{2} \\
47 \mathrm{~d}\end{array}$ \\
\hline $\mathrm{WCGF},{ }^{3} \%$ & 21 & 15 \\
\hline Corn silage, $\%$ & 10 & 18 \\
\hline Brome hay, \% & 65.5 & 65 \\
\hline Supplement, ${ }^{4} \%$ & 3.5 & 4 \\
\hline Intake, $\mathrm{kg} / \mathrm{d}$ & 8.3 & 7.5 \\
\hline \multicolumn{3}{|c|}{ Diet nutrient analysis, ${ }^{5} \%$} \\
\hline $\mathrm{CP}, \%$ & 14.7 & 14.5 \\
\hline RUP, \% CP & 21.7 & 22.3 \\
\hline Crude fat, $\%$ & 2.5 & 2.6 \\
\hline $\mathrm{NE}_{\mathrm{g}}, \mathrm{Mcal} / \mathrm{kg}$ & 0.88 & 0.85 \\
\hline Dietary cost, $\$ / \mathrm{d}$ & 0.80 & 0.85 \\
\hline
\end{tabular}

${ }^{1} \mathrm{DL}=$ heifers developed in a dry lot from weaning through the end of AI breeding.

${ }^{2} \mathrm{EXT}=$ heifers that previously grazed corn residue and dormant winter range then offered a dry lot diet for $47 \mathrm{~d}$ until AI breeding.

${ }^{3}$ Wet corn gluten feed.

${ }^{4}$ Ground corn, calcium carbonate, salt, trace mineral mix, and vitamin mix, formulated to provide $200 \mathrm{mg}$ of Rumensin (Elanco Animal Health, Greenfield, IN).

${ }^{5}$ Wet chemistry, Ward Laboratories Inc., Kearney, NE; RUP based on NRC (2000). 
Inc. or Lutalyse, Pfizer Animal Health). All cows received TAI approximately $66 \mathrm{~h}$ after CIDR removal and were administered a single 2-mL i.m. injection of $\mathrm{GnRH}$ (Ova-Cyst, Teva Animal Health Inc.). Within 5 d of AI breeding, cows and calves were sold to a single local producer each year where they grazed summer pasture until weaning of their calf. Cows were exposed to fertile bulls for a period not less than $45 \mathrm{~d}$. Approximately 45 d after TAI, first-service conception was assessed via transrectal ultrasonography. Conception to AI and final pregnancy rates for the second breeding season are only available for 2 of the $3 \mathrm{yr}$.

\section{Blood Collection and Assays}

Two blood samples ( $5 \mathrm{~mL}$ each) were collected $10 \mathrm{~d}$ apart before MGA feeding. Samples were collected via coccygeal venipuncture, cooled immediately on ice, and serum was harvested via centrifugation at $2,500 \times g$ for $20 \mathrm{~min}$ at $4^{\circ} \mathrm{C}$ and frozen at $-20^{\circ} \mathrm{C}$ until analysis. Serum progesterone concentrations were determined by direct solid-phase RIA (Coat-A-Count, Diagnostics Products Corp., Los Angeles, CA) without extraction as described by Melvin et al. (1999). Intra- and interassay CV were less than $10 \%$. Progesterone concentration greater than $1 \mathrm{ng} / \mathrm{mL}$ was interpreted to indicate ovarian luteal activity (Henricks et al., 1971).

\section{Economic Evaluation}

An economic evaluation was conducted using the procedure defined by Feuz (1992). Winter CR or dormant pasture grazing cost for a heifer calf was estimated to be one-half the cost of winter grazing for a mature cow, based upon heifer BW at weaning. All supplemental feeding and nonfeeding costs, including veterinary charges and trucking, were charged at an additional $\$ 0.36 / d$ in both systems. Summer grazing cost was estimated to be one-half the cost of summer grazing for a mature cow, based upon heifer BW before breeding. The sale value of the heifers at weaning and pregnancy diagnosis was calculated from the Nebraska average price reported by USDA Agricultural Marketing Service for each individual date (USDA-AMS, 2008). Budgets evaluated the economics from weaning until pregnancy diagnosis. The total cost and net return were calculated using the formula developed by Feuz (1992). The total value of all open and culled heifers was subtracted from the total development cost of the entire group of heifers. The total adjusted value of heifer development was then divided by the number of heifers exposed, to arrive at the total cost of a heifer entered into the system. Finally, this value was divided by the pregnancy rate, providing the cost of developing one pregnant heifer.

Net cost for 1 pregnant heifer $=$

(yr 1 cost - cull heifer value)/yearling conception rate.

\section{Statistical Analysis}

Because treatment was winter heifer development system and heifers were managed either on EXT or DL and replicated $3 \mathrm{yr}$, EXT field $(\mathrm{n}=3)$ or DL pen (n $=3$ ) were considered the experimental units for heifer performance and reproductive data. Continuous data were analyzed with PROC MIXED (SAS Inst. Inc., Cary, NC). The statistical model included winter development system as the fixed effect. Treatment nested with the effect of year was included as a random variable. Means were separated by LSD, and means were declared different at $P \leq 0.05$. The binomial data were logit-transformed and analyzed with PROC GLIMMIX.

\section{RESULTS AND DISCUSSION}

Heifer BW and ADG data are presented in Table 5. Heifers grazing EXT gained approximately $0.40 \mathrm{~kg}$ of BW/d less $(P=0.01)$ than heifers developed in the DL during the winter grazing period. The predicted $\mathrm{NE}_{\mathrm{g}}$ content of diets consumed during the winter was approximately $25 \%$ less for EXT heifers (Table 1) compared with DL (Tables 2, 3, and 4). In addition, the CP concentration provided to EXT heifers was approximately $8 \%$ less than the average dietary $\mathrm{CP}$ consumed by DL heifers. Fernandez-Rivera et al. (1989) conducted a growth response experiment and indicated $\mathrm{CP}$ was the first limiting factor for growing animals grazing CR. Thus, CP may have been the most limiting in the $\mathrm{CR}$ diets and perhaps affected ADG. The EXT heifers weighed $52 \mathrm{~kg}$ less $(P=0.05)$ when BW was measured immediately after returning from winter grazing compared with heifers developed in the DL. Diets consumed by EXT heifers in the dry lot were formulated to produce similar BW gains as DL heifers. The DL heifers had greater $(P=0.02)$ ADG for the entire weaning to breeding period and greater $(P$ $=0.02)$ prebreeding $\mathrm{BW}$, resulting in a $9 \%$ greater $(P$ $=0.02$ ) percentage of mature BW at breeding. Previous research on reduced-ADG heifer development has been conducted completely in the DL, under controlled conditions. No data exist in the literature comparing DL heifer development with a system utilizing lowquality winter forage from $\mathrm{CR}$ and standing dormant winter forage. The major challenge in managing this system is lack of current data to predict ADG of growing heifer calves while winter grazing with minimal supplementation. Data exist to assist in predicting ADG of growing steer calves grazing CR (Fernandez-Rivera and Klopfenstein, 1989; Gutierrez-Ornelas and Klopfenstein, 1991). Corn variety and harvesting efficiency are now substantially different from when the research was conducted. However, those experiments provide a basis for estimating ADG and designing an appropriate supplementation strategy. Data indicate RUP is a necessary nutrient for growing cattle and is limiting in CR (Fernandez-Rivera et al., 1989). Dried distillers grain 
Table 5. Effects of dry lot development or grazing a combination of corn residue and winter range on heifer BW gain and BW

\begin{tabular}{|c|c|c|c|c|}
\hline Trait & $\mathrm{DL}^{1}$ & $\mathrm{EXT}^{2}$ & SEM & $P$-value \\
\hline $\mathrm{n}$ & 3 & 3 & - & - \\
\hline Initial BW, kg & 253 & 253 & 3 & 0.97 \\
\hline Winter period $\mathrm{ADG},{ }^{3} \mathrm{~kg} / \mathrm{d}$ & 0.58 & 0.19 & 0.05 & 0.01 \\
\hline BW after winter grazing, $\mathrm{kg}$ & 331 & 279 & 11 & 0.05 \\
\hline Prebreeding $\mathrm{ADG},{ }^{4} \mathrm{~kg} / \mathrm{d}$ & 0.86 & 0.90 & 0.10 & 0.71 \\
\hline Prebreed BW, kg & 387 & 336 & 6 & 0.02 \\
\hline Weaning to breeding $A D G,{ }^{5} \mathrm{~kg} / \mathrm{d}$ & 0.68 & 0.42 & 0.03 & 0.02 \\
\hline Percentage of mature BW, $\%$ & 65 & 56 & 0.01 & 0.02 \\
\hline Pregnancy diagnosis BW, $\mathrm{kg}$ & 444 & 416 & 4 & 0.02 \\
\hline Summer ADG ${ }^{6} \mathrm{~kg} / \mathrm{d}$ & 0.47 & 0.67 & 0.05 & 0.05 \\
\hline Precalving BW, kg & 467 & 451 & 5 & 0.20 \\
\hline \multicolumn{5}{|c|}{$\begin{array}{l}{ }^{1} \mathrm{DL}=\text { heifers consuming a diet in a dry lot postweaning. } \\
{ }^{2} \mathrm{EXT}=\text { heifers supplemented } 3 \text { times per week with the equivalent of } 0.45 \mathrm{~kg} / \mathrm{d} 31 \% \mathrm{CP} \text { cube (DM basi } \\
\text { ostweaning while grazing corn residue and dormant winter range and subsequently moved to the dry lot. } \\
{ }^{3} \mathrm{ADG} \text { while grazing winter forage or feeding in the DL. } \\
{ }^{4} \mathrm{ADG} \text { in the period between heifers returning from winter grazing and the first breeding service. } \\
{ }^{5} \mathrm{ADG} \text { in the period between weaning and the first breeding service. }\end{array}$} \\
\hline
\end{tabular}

plus solubles (DDGS) is an excellent, readily available source of undegradable protein. The supplement provided to EXT heifers contained approximately $62 \%$ DDGS. Thus, supplementation may have been insufficient to improve ADG in EXT heifers. Gustad et al. (2006) found DDGS supplemented between 0.68 and $2.95 \mathrm{~kg} / \mathrm{d}$ to calves grazing $\mathrm{CR}$ increased ADG from 0.41 to $0.82 \mathrm{~kg} / \mathrm{d}$. Offering $2.25 \mathrm{~kg} / \mathrm{d}$ of WCGF has also resulted in improved ADG of young cattle grazing CR (Jordon et al., 2001). Further research is needed to determine the optimum amount and type of corn coproduct supplementation to replacement heifers grazing CR. Alternatively, there is anecdotal evidence of a learning curve associated with CR grazing and may be responsible for the reduced ADG of young heifers while grazing $\mathrm{CR}$ for the first time.

Perhaps the greatest concern associated with slow rates of postweaning heifer BW gain is a low prebreeding BW and the alteration of age at puberty. Traditionally, it has been recommended heifers reach approximately $65 \%$ of mature BW before the first insemination (Patterson et al., 1992). This recommendation stems from earlier data indicating heifers nutritionally restricted postweaning had a lighter prebreeding BW, fewer were pubertal at breeding, and pregnancy rates were reduced or breeding date delayed (Wiltbank et al., 1965, 1985; Arije and Wiltbank, 1971; Short and Bellows, 1971; Patterson et al., 1991). In addition to decreased pregnancy rates, nutritionally restricted heifers may calve late and continue to do so, leading to less lifetime productivity (Lesmeister et al., 1973). Moreover, heifers calving late in the season likely wean lighter calves, which are less valuable.

In the current study, reducing postweaning ADG allowed heifers to reach $56 \%$ of mature BW compared ( $P$ $=0.02)$ to DL heifers, which attained $65 \%$ of mature BW by breeding. The lighter prebreeding BW reduced $(P=0.01$; Table 6$)$ the percentage of EXT heifers at- taining puberty before MGA by $48 \%$. The decreased percentage of EXT heifers being pubertal was likely the result of several factors including growth rate, winter diet, possibly monensin supplementation, which was a function of diet quality, and other behavioral and environmental factors differing in each development system. These data agree with recent literature indicating reduced postweaning ADG resulting from lower diet quality, with or without moderate realimentation before breeding, reduces the percentage of heifers attaining puberty (Granger et al., 1990; Lalman et al., 1993; Buskirk et al., 1995, 1996; Marston et al., 1995; Lynch et al., 1997; Ciccioli et al., 2005; Gasser et al., 2006). Martin et al. (2008) indicated reducing the percentage of mature BW at breeding by approximately $6 \%$ resulted in a nonsignificant, $17 \%$ decrease in percentage of pubertal heifers at breeding. Further, a $5 \%$ reduction in BW at breeding resulted in an $11 \%$ reduction in percentage of heifers pubertal before breeding (Funston and Deutscher, 2004). Genetics may have adapted to minimize the negative effect of delayed puberty on firstservice conception. Previous research indicates no effect of moderate nutrient restriction leading to reduced ADG during postweaning development, regardless of pubertal effects, on first service conception or percentage of heifers calving to the first conception (Lalman et al., 1993; Buskirk et al., 1995; Lynch et al., 1997; Funston and Deutscher, 2004; Martin et al., 2008). Similarly, in the present study, grazing heifers on CR or winter grass for a portion of postweaning development did not affect $(P=0.23)$ AI conception rate compared with heifers developed in a DL. However, AI pregnancy rate tended to be less $(P=0.08)$ for EXT heifers. Perhaps the larger than previously reported reduction in postweaning $\mathrm{ADG}$ and percentage of pubertal heifers compared with the control group in this experiment affected reproduction. However, final pregnancy rate was not different $(P=0.38)$ between EXT and DL 
Table 6. Effects of dry lot development or grazing a combination of corn residue and winter range on heifer reproduction

\begin{tabular}{lcccc}
\hline \hline Trait & $\mathrm{DL}^{1}$ & $\mathrm{EXT}^{2}$ & $\mathrm{SEM}$ & $P$-value \\
\hline n, first season & 3 & 3 & - & - \\
Pubertal by AI, \% & 88 & 46 & 0.04 & 0.01 \\
Conceived to AI, first season, \% & 69 & 58 & 0.08 & 0.23 \\
Pregnant to AI, first season, \% & 64 & 54 & 0.06 & 0.08 \\
Pregnant, first season, \% & 94 & 92 & 0.04 & 0.38 \\
n, second season & 2 & 2 & - & - \\
Pregnant to AI, second season, \% & 62 & 66 & 0.08 & 0.61 \\
Final pregnancy rate, second season, \% & 93 & 84 & 0.14 & 0.56 \\
\hline \multicolumn{1}{l}{${ }^{1} \mathrm{DL}=$ heifers consuming a diet in a dry lot postweaning. } \\
${ }^{2} \mathrm{EXT}=$ heifers supplemented 3 times per week with the equivalent of $0.45 \mathrm{~kg} / \mathrm{d}$ 31\% CP cube (DM basis) \\
postweaning while grazing corn residue and dormant winter range and subsequently moved to the dry lot.
\end{tabular}

heifers. Nearly all previous research indicates postweaning $\mathrm{BW}$ gain restriction resulted in similar final pregnancy rates (Granger et al., 1990; Lalman et al., 1993; Buskirk et al., 1995; 1996; Lynch et al., 1997; Funston and Deutscher, 2004; Ciccioli et al., 2005; Gasser et al., 2006; Martin et al., 2008). The percentage of heifers calving in the first $21 \mathrm{~d}$ was similar $(P=0.30$; Table 7$)$ between treatments and greater than $70 \%$ for the entire group, indicating heifers not becoming pregnant to AI became pregnant at the subsequent estrus. As mentioned previously EXT heifers were significantly less pubertal before synchronization but had similar pregnancy rates. It is possible the synchronization system utilized in this study potentially prevented decreased reproductive outcomes in the EXT treatment because MGA has been shown to induce puberty in noncycling beef females (Jaeger et al., 1992). However, it is unlikely GnRH used at TAI in yr 1 induced puberty beyond the effects of MGA, as synchronization rates in yr 2 and 3 were $90 \%$ without $\mathrm{GnRH}$ and AI, and final pregnancy rate was numerically least for yr 1 . Martin et al. (2008) supplemented MGA to heifers developed to approximately $50 \%$ of mature $\mathrm{BW}$ before natural service mating and did not demonstrate an advantage in pregnancy rate or subsequent calving date. Greater than $70 \%$ of these heifers were pubertal before MGA feeding; also, it is important to note these were crossbred heifers, which may have inherently greater fertility and perhaps do not require the level of development a more straight-bred heifer requires. Further research is needed to determine if low-input system pregnancy rate is acceptable without induced puberty and using natural service rather than $\mathrm{AI}$ in more straight-bred heifers.

Heifers originally developed by grazing winter forage experienced compensatory BW gain during the summer with a greater $(P=0.05$; Table 5$)$ ADG than heifers originally in the DL. Although EXT heifers had less $(P=0.02) \mathrm{BW}$ at pregnancy diagnosis, the increased rate of ADG may have contributed to the reproductive improvement in the EXT heifers as evidenced by similar final pregnancy rates. Perhaps, postweaning ADG is less influential for subsequent reproduction than preweaning growth (Patterson et al., 1992). Buskirk et al. (1996) found heifer calves receiving creep feed while nursing their dams reached puberty earlier and had greater pregnancy rates; however, postweaning BW gain did not influence reproduction. These data and previous literature suggest postweaning heifer development to less than $65 \%$ of mature BW at breeding will produce satisfactory pregnancy rates.

Heifer BW before calving was not different $(P=$ 0.20; Table 5) for EXT compared with DL heifers. Calf production data are displayed in Table 7. As indicated, percentage of heifers calving in the first $21 \mathrm{~d}$ of the season was not different $(P=0.30)$. Calf birth date was also not different $(P=0.20)$ between EXT and

Table 7. Effects of dry lot development or grazing a combination of corn residue and winter range on calf production

\begin{tabular}{lcccc}
\hline \hline Trait & DL $^{1}$ & EXT $^{2}$ & SEM & $P$-value \\
\hline $\mathrm{n}$ & 3 & 3 & - & - \\
Calved in first 21 d, \% & 81 & 72 & 0.05 & 0.30 \\
Calf birth date, Julian d & 70 & 74 & 1.7 & 0.20 \\
Calf birth BW, kg & 34 & 34 & 0.63 & 0.55 \\
Dystocia score & 1.3 & 1.4 & 0.11 & 0.35 \\
Sex, \% male & 47 & 49 & 0.06 & 0.83 \\
\hline${ }^{1} \mathrm{DL}=$ heifers consuming a diet in a dry lot postweaning. & & \\
${ }^{2} \mathrm{EXT}=$ heifers supplemented 3 times per week with the equivalent of $0.45 \mathrm{~kg} / \mathrm{d}$ 31\% CP cube (DM basis) \\
postweaning while grazing corn residue and dormant winter range and subsequently moved to the dry lot. \\
${ }^{3}$ Scoring system 1 to 5: 1 = no assistance; 2 = easy pull; 3 = mechanical pull; 4 = hard mechanical pull; and \\
$5=$ cesarean section.
\end{tabular}


Table 8. Economic evaluation of heifers developed in a dry lot or developed grazing a combination of corn residue and winter range

\begin{tabular}{lcrrr}
\hline \hline Trait & DL $^{1}$ & EXT $^{2}$ & SEM & $P$-value \\
\hline Initial weaned value, $\$ /$ heifer & 625 & 624 & - & - \\
Winter feed cost, $\$ /$ heifer & 93 & 60 & 4.37 & $<0.01$ \\
Spring feed cost, $\$ /$ heifer & 56 & 47 & 7.45 & 0.43 \\
Summer feed cost, $\$ /$ heifer & 88 & 88 & 0.88 & 0.82 \\
Total feeding cost, $\$ /$ heifer & 237 & 195 & 4.57 & $<0.01$ \\
Total development cost, ${ }^{3}$ /heifer & 982 & 941 & 4.48 & $<0.01$ \\
Cull heifer value, $\$ /$ heifer exposed & 53 & 77 & 26.67 & 0.55 \\
Net cost of 1 pregnant heifer, $\$$ & 985 & 940 & 3.35 & $<0.01$ \\
\hline${ }^{1}$ DL $=$ heifers consuming a diet in a dry lot postweaning. & & & \\
${ }^{2}$ EXT $=$ heifers supplemented 3 times per week with the equivalent of 0.45 kg/d 31\% CP cube (DM basis) \\
postweaning while grazing corn residue and dormant winter range and subsequently moved to the dry lot. \\
${ }^{3}$ Including all fixed and variable costs associated with interest, estrus synchronization, feed delivery, and \\
breeding costs.
\end{tabular}

DL heifers. Percentage of male calves and calf birth BW were not different $(P \geq 0.55)$. Dystocia score was also not different $(P=0.35)$ among EXT and DL heifers. With the exception of calving date, these data are similar to Funston and Deutscher (2004) and Martin et al. (2008). Those authors indicate no difference in any calving characteristic, except for calving date. Martin et al. (2008) indicate heifers developed to $50 \%$ of mature BW at breeding calved $7 \mathrm{~d}$ later than heifers developed to $55 \%$ of mature BW. The EXT heifers in the current study reached $56 \%$ of mature BW at breeding; thus, targeting approximately 55 to $56 \%$ of mature BW appears to be acceptable. Second-season AI conception rate and final pregnancy rate was also not different $(P$ $\geq 0.56$; Table 6$)$. This is similar to data reported by Funston and Deutscher (2004) and Martin et al. (2008). Furthermore, Funston and Deutscher (2004) report no difference in rebreeding or calf production through the fourth calf between heifers developed to 53 or $58 \%$ of mature BW by breeding.

The economic data are reported in Table 8. With increasing commodity cost, it is important to reduce input costs, especially by limiting the use of harvested feedstuffs. Corn residue is abundant in the Midwest, making it an attractive, inexpensive forage source. The cost of the winter grazing system with $0.45 \mathrm{~kg} / \mathrm{d}$ of a supplement was approximately $\$ 0.46$ heifer/d. In contrast, developing heifers in the DL cost $\$ 0.75$ heifer $/ \mathrm{d}$ when averaged across the winter and spring phases. Limiting the duration of DL feeding by grazing CR or winter grass for at least $135 \mathrm{~d}$ postweaning reduced $(P$ $<0.01$ ) prebreeding heifer feed cost by $\$ 42$ compared with DL development for the entire prebreeding period. There was a similar $(P=0.37)$ number of heifers culled in each group, resulting in a similar $(P=0.55)$ cull heifer value. Subtracting the cull heifer value from total development costs reveals EXT development reduced $(P<0.01)$ cost by $\$ 45$ per pregnant heifer after accounting for differences in pregnancy rate. Funston and Deutscher (2004) reported a $\$ 22 /$ heifer savings from developing heifers to $53 \%$ of mature $\mathrm{BW}$ by breeding compared with heifers reaching $58 \%$ of mature BW.
Similarly, developing heifers in a DL to $50 \%$ of mature BW reduced the cost of 1 pregnant heifer by $\$ 24$ compared with development to 55\% (Martin et al., 2008). An economic analysis conducted by Feuz (2001) compared differing percentages of mature BW a heifer reached with reproductive and economic considerations. Feuz (2001) determined that reducing percentage of mature BW from 65 to $55 \%$ reduced the net cost of developing 1 pregnant heifer by $\$ 19 /$ heifer. Perhaps more interestingly, this reduction in cost was noted in spite of a $9 \%$ reduction in pregnancy rate. These data support the cost reduction noted in the current study.

In the present study, winter grazing was a suitable alternative to a DL for heifer development. These and previous data indicate developing heifers to less than $65 \%$ of mature BW by breeding is economically superior to a greater BW development. Targeting approximately $56 \%$ of mature BW appears to result in acceptable reproduction and calf production. Furthermore, developing heifers utilizing winter grazing of $\mathrm{CR}$ and winter grass can substantially reduce cost and may be more sustainable than DL development.

\section{LITERATURE CITED}

Arije, G. F., and J. N. Wiltbank. 1971. Age and weight at puberty in Hereford heifers. J. Anim. Sci. 33:401-406.

Buskirk, D. D., D. B. Faulkner, W. L. Hurley, D. J. Kesler, F. A. Ireland, T. G. Nash, J. C. Castree, and J. L. Vicini. 1996. Growth, reproductive performance, mammary development, and milk production of beef heifers as influenced by prepubertal dietary energy and administration of bovine somatotropin. J. Anim. Sci. 74:2649-2662.

Buskirk, D. D., D. B. Faulkner, and F. A. Ireland. 1995. Increased postweaning gain of beef heifers enhances fertility and milk production. J. Anim. Sci. 73:937-946.

Ciccioli, N. H., S. L. Charles-Edwards, C. Floyd, R. P. Wettemann, H. T. Purvis, K. S. Lusby, G. W. Horn, and D. L. Lalman. 2005. Incidence of puberty in beef heifers fed high- or lowstarch diets for different periods before breeding. J. Anim. Sci. 83:2653-2662.

Faulkner, D. B., T. J. Klopfenstein, T. N. Trotter, and R. A. Britton. 1985. Monensin effects on digestibility, ruminal protein escape and microbial protein synthesis on high-fiber diets. J. Anim. Sci. 61:654-660. 
Fernandez-Rivera, S., and T. J. Klopfenstein. 1989. Diet composition and daily gain of growing cattle grazing dryland and irrigated cornstalks at several stocking rates. J. Anim. Sci. 67:590-596.

Fernandez-Rivera, S., T. J. Klopfenstein, and R. A. Britton. 1989. Growth response to escape protein and forage intake by growing cattle grazing cornstalks. J. Anim. Sci. 67:574-580.

Feuz, D. M. 1992. Replacement beef heifer economics: When prices and reproductive performance are uncertain. Am. Soc. Farm Managers Rural Appraisers 56:61-66.

Feuz, D. M. 2001. Economics of young female management. Proc. Range Beef Cow Symp., Casper, WY. Univ. Wyoming, Laramie.

Funston, R. N., and G. H. Deutscher. 2004. Comparison of target breeding weight and breeding date for replacement beef heifers and effects on subsequent reproduction and calf performance. J. Anim. Sci. 82:3094-3099.

Gasser, C. L., E. J. Behlke, D. E. Grum, and M. L. Day. 2006. Effect of timing of feeding a high-concentrate diet on growth and attainment of puberty in early-weaned heifers. J. Anim. Sci. 84:3118-3122.

Granger, A. L., W. E. Wyatt, F. G. Hernbry, W. M. Craig, and D. L. Thompson Jr. 1990. Effects of breed and wintering diet on heifer postweaning growth and development. J. Anim. Sci. 68:304-316.

Gustad, K., T. Klopfenstein, G. Erickson, J. MacDonald, K. Vander Pol, and M. Greenquist. 2006. Dried distillers grains supplementation to calves grazing corn residue. Nebraska Beef Rep. MP 88-A:36-37.

Gutierrez-Ornelas, E., and T. J. Klopfenstein. 1991. Changes in availability and nutritive value of different corn residue parts as affected by early and late grazing seasons. J. Anim. Sci. 69:1741-1750.

Henricks, D. M., D. R. Lamond, J. R. Hill, and J. F. Dickey. 1971. Plasma progesterone concentrations before mating and in early pregnancy in the beef heifer. J. Anim. Sci. 33:450-454.

Jaeger, J. R., J. C. Whittier, L. R. Corah, J. C. Meiskes, K. C. Olson, and D. J. Patterson. 1992. Reproductive response of yearling beef heifers to a melengestrol acetate-prostaglandin $F_{2 a}$ estrus synchronization system. J. Anim. Sci. 70:2622-2627.

Jordon, D. J., T. Klopfenstein, and T. Milton. 2001. Wet corn gluten feed supplementation of calves grazing corn residue. Nebraska Beef Rep. MP 76-A:41-43.

Lalman, D. L., M. K. Peterson, R. P. Ansotegui, M. W. Tess, C. K. Clark, and J. S. Wiley. 1993. The effects of ruminally undegradable protein, propionic acid, and monensin on puberty and pregnancy in beef heifers. J. Anim. Sci. 71:2843-2852.

Larson, D. M., A. S. Cupp, and R. N. Funston. 2009. Extending grazing in heifer development systems decreases cost without compromising production. Proc. West. Sec. Am. Soc. Anim. Sci. 60:67-71.

Lesmeister, J. L., P. J. Burfening, and R. L. Blackwell. 1973. Date of first calving in beef cows and subsequent calf production. J. Anim. Sci. 36:1-6.
Lynch, J. M., G. C. Lamb, B. L. Miller, R. T. Brandt Jr., R. C. Cochran, and J. E. Minton. 1997. Influence of timing of gain on growth and reproductive performance of beef replacement heifers. J. Anim. Sci. 75:1715-1722.

Marston, T. T., K. S. Lusby, and R. P. Wettemann. 1995. Effects of postweaning diet on age and weight at puberty and milk production of heifers. J. Anim. Sci. 73:63-68.

Martin, J. L., K. W. Creighton, J. A. Musgrave, T. J. Klopfenstein, R. T. Clark, D. C. Adams, and R. N. Funston. 2008. Effect of prebreeding body weight or progestin exposure before breeding on beef heifer performance through the second breeding season. J. Anim. Sci. 86:451-459.

Melvin, E. J., B. R. Lindsey, J. Quintal-Franco, E. Zanella, K. E. Fike, C. P. Van Tassell, and J. E. Kinder. 1999. Circulating concentrations of estradiol, luteinizing hormone, and folliclestimulating hormone during waves of ovarian follicular development in prepubertal cattle. Biol. Reprod. 60:405-412.

NRC. 2000. Nutrient Requirements of Beef Cattle. 7th ed. Natl. Acad. Press, Washington, DC.

Patterson, D. J., L. R. Corah, J. R. Brethour, M. F. Spire, J. J. Higgins, G. H. Kiracofe, J. S. Stevenson, and D. D. Simms. 1991. Evaluation of reproductive traits in Bos taurus and Bos indicus crossbred heifers: Effects of post-weaning energy manipulation. J. Anim. Sci. 69:2349-2361.

Patterson, D. J., R. C. Perry, G. H. Kiracofe, R. A. Bellows, R. B. Staigmiller, and L. R. Corah. 1992. Management considerations in heifer development and puberty. J. Anim. Sci. 70:40184035 .

Roberts, A. J., T. W. Geary, E. E. Grings, R. C. Waterman, and M. D. MacNeil. 2009. Reproductive performance of heifers offered ad libitum or restricted access to feed for a 140-d period after weaning. J. Anim. Sci. 87:3043-3052.

Roberts, A. J., S. I. Paisley, T. W. Geary, E. E. Grings, R. C. Waterman, and M. D. MacNeil. 2007. Effects of restricted feeding of beef heifers during the postweaning period on growth, efficiency and ultrasound carcass characteristics. J. Anim. Sci. 85:2740-2745.

Short, R. E., and R. A. Bellows. 1971. Relationships among weight gains, age at puberty and reproductive performance in heifers . J. Anim. Sci. 32:127-131.

USDA-AMS. 2008. Nebraska weekly feeder cattle auction summary. Accessed Jul. 22, 2008. http://www.ams.usda.gov/mnreports/ wh_ls795.txt.

Wiltbank, J. N., J. Bond, and E. J. Warwick. 1965. Influence of total feed and protein intake on reproductive performance of the beef female through the second calving. USDA Tech. Bull. 1314. Washington, DC.

Wiltbank, J. N., S. Roberts, J. Nix, and L. Rowden. 1985. Reproductive performance and profitability of heifers fed to weigh 272 or $318 \mathrm{~kg}$ at the start of the first breeding season. J. Anim. Sci. $60: 25-34$. 
References

This article cites 29 articles, 25 of which you can access for free at: http://jas.fass.org/cgi/content/full/89/5/1595\#BIBL 